\title{
Morality vs Immorality in the Miserable Life of Daniel Defoe's Moll Flanders
}

\author{
Vicky Tchaparian \\ Lebanese University
}

\begin{abstract}
Defoe's novel, Moll Flanders, the story of a thief, a criminal, a whore, a mistress, a lady, a lover, a beggar, and a plantation owner who lives the life of a repentant at 70, reveals Moll's both high and low morals. In the present paper I try to reveal the fact that Moll Flanders, the protagonist, and the first person narrator of the novel, speaks in the voice of Defoe who had lived a life of both vice and virtue with all its extremes. Moll Flanders represents the age Defoe lived, along with its harsh and corrupt judicial system, the poverty, the low level of life in the English society, and the injustice of the patriarchy, where love and marriage were commodities in the market called life. In the society where Moll lived, women got married either for money or for title but never for love. Thus, Moll, having neither money nor title, and urging to become a lady, passed through different stages in her life living in vice but later repenting and living in virtue.
\end{abstract}

Key words: Moll Flanders, criminal, immorality, Newgate Prison, mistress, minister, lady, money.

\section{Introduction}

At the time when Daniel Defoe wrote his Fortunes \& Misfortunes of the Famous Moll Flanders, men dominated the world and England was living black days after the horrible Fire and the Plague that had added on the misfortunes of the poor. In his Preface to the novel Defoe states that the tale is meant to convey a serious moral although Moll's autobiography which details her scandalous sexual and criminal adventures, may reveal the opposite. 
Moll Flanders is depicted to be one of the poor victims of the corrupt social and judicial systems of the $18^{\text {th }}$ century; she is a young girl of anonymous parenthood, who had fallen in love, but had not been able to be happily married because of social and economic reasons. Moll's dream had never been to live a life of vice, whoredom, and theft; however, her life circumstances had not offered her anything better, so, she had ended up living in immorality.

Defoe, being an active member of the low class, and working hard in trade to move forward in life, knew well about the miseries of the low class people in general and women in particular; women who had only one chance in life called "marriage." However, life was a market, and marriage was a very expensive commodity. A woman had to have either money or title to be able to get a good husband and live virtuously, and not all women were so lucky.

A Typical $18^{\text {th }}$ Century Woman Longing to Live in Virtue, but Living in Vice

Although many economic and social changes occurred in England during the $18^{\text {th }}$ century, yet, obviously men still dominated the world. Under the influence of the patriarchal society and the Industrial Revolution, men were superior to women not only in social status but in economic status as well. Defoe, one of the pioneers in the world of trade and economy of the $18^{\text {th }}$ century England, who participated effectively in creating the novel genre, has skillfully carved and engraved his unique character, Moll Flanders, cultivating in her much of him and more of the women of his age.

The epidemic of the great plague that ravaged London from 1665 to 1666 and killed an estimated 100,000 people, almost a quarter of London's population in 18 months, along with the Horrible Fire of London that swept the central parts of the city from 2 till 6 September $1666(<$ https://en.wikipedia.org/wiki/

Great_Fire_of_London>) effected the English society in general and its lower class in particular and revealed the very big gap between the rich and the poor. Defoe, who participated effectively in creating the English middle class, presents a detailed and realistic picture of the life of the poor, including violence on the streets, theft, prostitution, and alike. In Moll Flanders, Defoe 
depicts the lives of those who could not inherit money and try theft even though the law was harsh, death penalty was frequently inflicted, and executions were public events. Defoe's protagonist, Moll Flanders, truly represents all those penalties along with executions and transportation overseas. She represents innocent women who would like to have their own family, get married with their one and only lover, but have been deprived of their senses and been converted to either criminals or prostitutes who would fight using any means to be able to survive. Moll, the heroin, who wrote her autobiography at the age of seventy, was aware of the fact that it was a man's world; that money and class were the only means for a woman of her time to live a comfortable life, however, she also knew that she couldn't afford her dream life since she was poor and of unknown parenthood.

In the $18^{\text {th }}$ century England, "being a woman was a misfortune and being a woman without money was a double misfortune" (MA Wenying 2015:2). Considering this, Moll understood that no matter how much money she made and how many possessions she had, she would never be accepted by the English society as a fine lady. According to Holzner (2001:52), "Moll Flanders was merely a victim of the male-centered society, and she was driven by all the forces of the world to pursue the immoral things." She came to the conclusion that the only means for her to afford a living was to make money because she believed that nothing would save her but money, thus she said;

[...] if a young woman has beauty, birth, breeding, wit, sense, manners, modesty, and all these to an extreme, yet if she has not money, she's nobody, she had as good want them all for nothing but money now recommends a woman; the men play the game all into their own hands. (p. 20)

Moll learned that money was the only way for a virtuous life, that she was living in a man's world, and that women had restricted roles. She knew she 
could do nothing alone, and that is why she always searched for a companion, usually a man, who could support her with material things,

'tis evident men can be their own advisers, and their own directors, and know how to work themselves out of difficulties and into business better than women; but if a woman has no friend to communicate her affairs to, and to advise and assist her, 'tis ten to one but she is undone $[\ldots] .(\mathrm{p} .112)$

Having this in mind, Moll never stopped getting married. She even left her maternal feelings aside to save herself from poverty and loneness. At the time when Defoe wrote Moll Flanders, there existed in England essentially no difference in the punishment received by those who committed theft and those who committed murder. Moll, the innocent little girl, born in Newgate prison, from a mother who was about to be hanged for a petty theft, was saved because of her pregnancy and was later transported to the colonies, leaving the oneand-a-half-year-old Moll in bad hands. Later in her life, Moll came to understand that life in the $18^{\text {th }}$ century England was only a market where love and affection were cheap commodities, whereas title and money were all what a woman needed to survive. Moreover, "In the patriarchal society, men and women were unequal, not only in the marital life, but also in the social life" (Erikson 1986:89). So, men could get married with a rich or a famous man's daughter, and keep poor girls as their lovers and mistresses.

[...] men chose mistresses indeed by the gust of their affection, and it was requisite to a whore to be handsome, well-shaped, have a good mien and a graceful behavior; but that for a wife, no deformity would shock the fancy, no ill qualities the judgment; the money was the thing; the portion was neither crooked nor monstrous, but the money was always agreeable, whatever the wife was. (p.60) 
Moll, having born in such a society, with neither money nor title, lived her childhood working and learning how to sew and make her own living. She was a forceful, persistent, and an attractive woman who obtained her way alone in life and was convinced that men were in love with her and that she was beautiful enough to get any man she wanted. She said,

\section{If a young women once thinks herself handsome, she never doubts the truth of any man that tells her he is in love with her; for if she believes herself charming enough to captive him, 'tis natural to expect the effects of it. (p.23)}

However, along with her wit, she lived twelve years as a whore, five times as a wife (once to her own brother), twelve years as a thief, and eight years as a transported criminal in Virginia. By the time Moll was eight, she didn't intend to become a servant, even though town authorities expected her to be one. Instead, she intended to become a "gentlewoman," like a neighbor who seems to earn her living by needlework but is actually a prostitute. Because of her looks and cleverness, Moll became a favorite of the wealthy ladies in town who enjoyed visiting her and gave her money for her living expenses aside from her money for needlework. So, by the time she became fourteen she was taken in by one of the wealthy women, and it was here that her journey in real life tribulations and miseries started.

A poor and beautiful orphan, who had no one to support her, serving in a rich family home would definitely be led to trouble; Moll and the elder brother of the well-off woman's family had a relationship, yet, the elder brother turned her into the wife of his younger brother (who was more interested in love, and less interested in money, and more importantly was naïve enough to believe Moll was the innocent powerless virgin in love with him). As Moll said, [...]he diligently did [...] cheat him, and had the Thanks of a faithful Friend for shifting off his Whore into his Brothers Arms for a Wife (p. 52). 
Knowing that only money could save her from the harshness of life and the society, knowing that life is not a fair game, that the elder brother whom she so dearly loved would never accept her as his wife since she lacked title and money, Moll accepted the offer of the younger brother who was less interested in class and was more in love with her. However, after living only five years as the wife of the well-off family's son, she was left alone as a widow with no money and no one to turn to. Being in such a situation, in such a place as England during the $18^{\text {th }}$ century, Moll increased her criminal activities (which included no killing but stealing and prostitution). She also kept spreading rumors about her riches to get a husband every time she lost one. Her theory was that if England had provided properly for orphans she would not have fallen into bad hands and would not have needed to fend/maintain for herself before she could make her way in the world. The result of the acts she performed to achieve these goals was the transformation of a beautiful innocent young girl into a hardened middle-aged criminal who was finally captured and sent to Newgate Prison. Thus, dreaming to live a life of virtue in a happy and a rich family, with her lover becoming her husband, the misfortune of being a poor orphan did not help Moll to realize her dream, but obliged her to live in vice, become a criminal, and be transported to Virginia to work at the plantations.

However, one might ask, what the difference between virtue and vice is. Virtue is "a behavior that shows high moral standards. Doing what is right and avoiding what is wrong. The opposite of virtue is vice." According to the same source, vice means, "a practice, behavior, or habit generally considered immoral, sinful, criminal, rude, taboo, depraved, or degrading in the associated society" (<https://en.wikipedia.org.>). According to Merriam Webster's dictionary, virtue means "morality, a particular moral excellence" and vice is "sexual immorality, especially prostitution" (Webster, 1993).

Considering the definition of the word vice according to Merriam Webster's dictionary, it can be said that Moll proved to be immortal throughout her life, since she had committed prostitution and had played the role of the mistress for many men. Moreover, if vice means rude, and degrading in the 
society, according to the encyclopedia, Moll's behavior also proved to be so rude to her children, leaving them careless and going in search of new husbands. She was also a criminal - during her lifetime, even a petty theft was considered to be a crime. However, she confirmed that had it not been the corruption of the English government at her time, shelters would be built for the orphans to live in as was the practice in France. Then, Moll wouldn't have been through all the miseries in her life.

On the other hand, the encyclopedic definition of virtue ("a behavior that shows high moral standards. Doing what is right and avoiding what is wrong") can be applied to Moll Flanders' life in the way that, every time she had a husband, Moll didn't cheat on him. She was faithful to all her husbands during the times she was married (considering the fact that she had officially been married for five times), and she avoided any other men during those times. Moreover, although she was considered a criminal and a thief, she only stole because she was poor and had nobody to provide her with her necessities. She said,

I have been told that in one of neighbor nations, whether it be in France or where else I know not, they have an order from the king, that when any criminal is condemned, either to die, or to the galleys, or to be transported, if they leave any children, as such are generally unprovided for, by the poverty or forfeiture of their parents, so they are immediately taken into the care of the Government, and put into a hospital called the House of Orphans, where they are bred up, clothed, fed, taught, and when fit to go out, are placed out to trades or to services, so as to be well able to provide for themselves by an honest, industrious behavior. 
Thus, according to Moll, if the English government provided for the orphans as the French government did during the $18^{\text {th }}$ century, if she herself was able to live at ease, regardless of her parenthood, she wouldn't have been condemned with all the crimes and would have lived a decent life.

\section{Conclusion}

Thus, Moll, a poor orphan of unknown parenthood, born in Newgate Prison, longed for a life of virtue, but living in such a society as the $18^{\text {th }}$ century English, where title and money were to define a person's fate, she was doomed to live a life of vice. Nevertheless, according to the definitions of vice and virtue, Moll had qualities that proved her to adhere to both. She condemned the English government for making her live a life of vice since she didn't have anyone to protect her nor to provide for her. Throughout the novel, Moll's dual nature is revealed shifting from vice to virtue and vice versa. Sometimes, she was a repentant woman rebuking herself for her misdeeds, and other times she was a ruthless pursuer of ill-gotten wealth, giving the excuse that a young girl in poor circumstances had the right to find support in the best way she could. Eventually, having got married for five times, and giving birth to a dozen children from different fathers, Moll's wit brought her release from prison and her transportation to Virginia. There, with Jemmy, her favorite husband, she was able to become, in a year's time, a wealthy plantation owner and repented for all the wrong deeds she had committed in her life.

\section{References:}

1. Erikson, R.A. (1986) Mother Midnight: Birth, Sex Fate in EighteenthCentury Fiction. New York: AMS Press Inc.

2. Great Plague of London (copyright 2019) Wikipedia. Available at: JSTOR database <en.wikipedia.org/wiki/Great_Plague_of_London> [Accessed March 2019].

3. Great Fire of London. (Copyright 2019) Wikipedia. <https://en. wikipedia.org/wiki/Great_Fire_of_London> [Accessed February 2019]. 
4. Holzner, J. (2001) The Taboo against Female Aggression in Moll Flanders, Lady Audrey's Secret, and Alias Grace. Dissertation. Huntsville, Alabama: The University of Alabama.

5. Wenying Zhang (2015) The Feminist Thoughts of Moll Flanders in Moll Flanders. // Journal of Literature and Art Studies. March 2015, Vol. 5, No. 3, pp.177-180. doi:10.17265/21 59-5836/2015.03.003. Changchun University, Changchun, China.

6. Webster, M. (1993) Merriam-Webster's Collegiate Dictionary $10^{\text {th }}$ edition. Springfield, Massachusetts, USA.

7. Wikipedia. The Free Encyclopedia. Available at: JSTOR database $<$ https://en.wikipedia.org> [Accessed May 2019].

\section{Source of Data}

1. Defoe, D. (2008) Moll Flanders. New Immeuble Esseily, Place Riad Solh, Beirut: York Press.

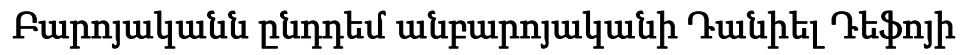

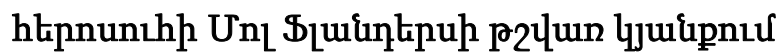

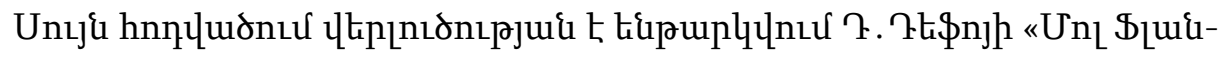

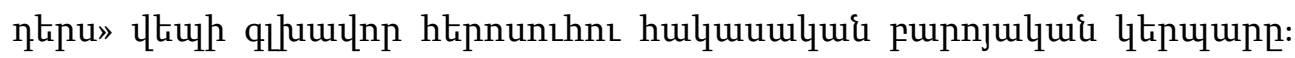

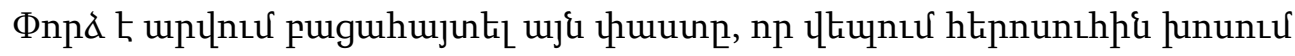

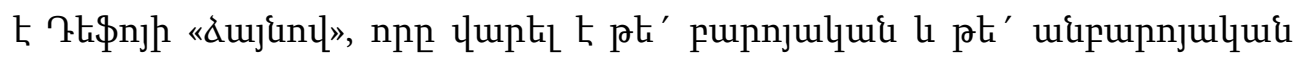

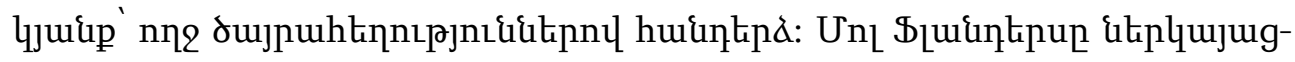

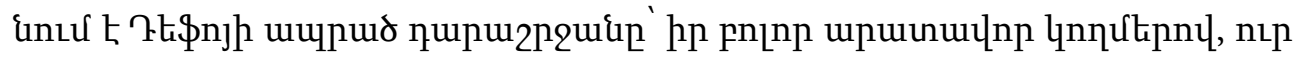

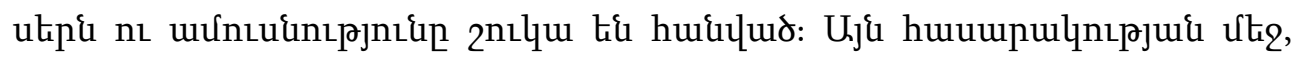

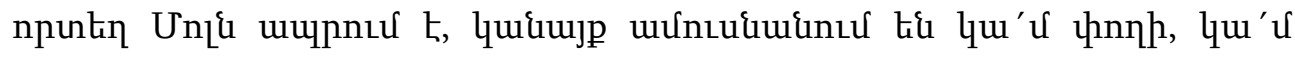

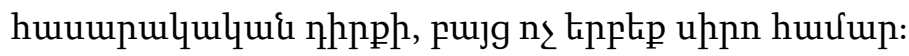

Received by the Editorial Board 19.12.2018

Recommended for publication by the reviewers 30.01.2019

Accepted for print 22.04.2019 